주문맥혈전증을 동반한 거대 간세포암 환자에서 정위 체부 방사선치료와 sorafenib 병합으로 종양의 완전관해 유도 후 위궤양천공이 발생한 1예

동남권원자력의학원 ${ }^{1}$ 내과학교실, ${ }^{2}$ 영상의학교실, ${ }^{3}$ 방사선종양학교실

황상연 $^{1} \cdot$ 이선미 ${ }^{1} \cdot$ 임정우 $^{1} \cdot$ 김준석 $^{1} \cdot$ 안상부 $^{2} \cdot$ 지은경 $^{2} \cdot$ 최철원 $^{3} \cdot$ 양광모 $^{3}$

\title{
A Case of Perforation of Gastric Ulcer after Complete Remission of Huge Hepatocellular Carcinoma Invading Main Portal Vein with Combination Therapy of Stereotactic Body Radiation Therapy and Sorafenib
}

Sang Youn Hwang', Seon-Mi Lee', Jung Woo Im¹, Joon Suk Kim¹, Sang Bu Ahn², Eun Kyeong Ji², Chul Won Choi', Gwang-Mo Yang ${ }^{3}$

${ }^{1}$ Departments of Internal Medicine and Gastrointestinal Cancer Center, ${ }^{2}$ Radiology and ${ }^{3}$ Radiation Oncology, Dongnam Institute of Radiological and Medical Sciences, Busan, Korea

Received Mar. 24, 2014

Revised Mar. 27, 2014

Accepted Mar. 27, 2014
Hepatocellular carcinoma ( $\mathrm{HCC}$ ) patients with main portal vein invasion have a poor prognosis associated with a median survival time of 2.7 months. Though many guidelines recommended sorafenib in HCC patients with macrovascular invasion (MVI), many clinicians or centers still select locoregional therapy (LRT) such as transarterial chemoembolization (TACE), radiation therapy (RT), or combination with LRT and sorafenib because the survival improvement by sorafenib only is expected to be shorter than that without MVI. However this multidisciplinary approach may increase treatment related toxicity such as liver failure etc. Stereotactic body radiation therapy (SBRT) is new technology providing very highly conformal ablative radiation dose for a small numbers (3-5 fractions) of large fraction size and is expected to new effective modality for HCC with MVI. Based on above suggestions, we herein offer our experience of a patient with perforation of radiation induced gastric ulcer after complete remission of tumor and main portal vein thrombosis by combination therapy of SBRT and sorafenib. Further study, maybe regarding a combination of locoregional and systemic therapy, is necessary on how to manage HCC patients with main portal vein invasion. (J Liver Cancer 2014;14:46-52)

Keywords: Hepatocellular carcinoma; Portal vein invasion; Stereotactic body radiotherapy; Sorafenib; Gastric ulcer perforation

\section{Corresponding author: Sang Youn Hwang}

Department of Internal Medicine, Gastrointestinal Cancer Center, Dongnam Institute of Radiological \& Medical Sciences 40 Jwadong-gil, Jangan-eup, Busan 619-953, Korea

Tel. +82-51-720-5114, Fax. +82-51-720-5992

E-mail; mongmani@hanmail.net
서 론

간세포암의 문맥 침범은 autopsy data에서 그 유병률이 44\%-62.8\%, clinical data에서는 31.4\%-34\%로 상대적으로 흔한 것으로 보고되고 있고 간내 암의 파종성 전이, 간기능 의 저하, 문맥압 항진을 통한 정맥류 출혈, 간성 혼수 등의 합병증 증가를 통해 예후가 불량한 것으로 알려져 있다. ${ }^{1-4}$ 
특히 주문맥 침범의 경우는 극히 예후가 불량하여 중앙생존 기간이 2.7 개월에 불과하다. ${ }^{5}$ 현재까지는 모든 가이드라인 에서 문맥 침범이 있는 경우 sorafenib을 사용할 것을 권고 하고 있지만 혈관 침범을 동반한 간세포암 환자에서의 sorafenib 사용에 의한 중앙생존기간은 5-8개월이며, 주문 맥 침범의 경우 효과가 더 떨어질 것으로 예상되어 실제 임 상에서는 여전히 경동맥 화학 색전술, 방사선 요법 등의 국 소치료 혹은 전신치료를 단독 혹은 병합하고 있는 실정이며 선택된 환자에서 치료 후에 암의 관해 혹은 안정화를 경험 하기도 한다. 하지만 대부분 종양의 범위가 광범위하거나 문맥혈류가 불량하여 종양의 완전관해가 힘들거나 간농양, 간부전 등의 치료 합병증을 경험하기도 한다. 저자들은 위 의 배경에 맞춰 주문맥 침범을 동반한 거대 간세포암종 환 자에서 정위 체부 방사선 치료, sorafenib을 병합하여 완전 관해를 경험하였으나 위궤양 천공이 발생한 증례를 경험하 였기에 이를 보고하는 바이다.

\section{증 례}

\section{1. 임상소견}

61세 남자 환자로 만성 B형 간염으로 2008년부터 entecavir $0.5 \mathrm{mg}$ 복용 중이다. 2011년 10월 타 병원에서 시행한 복
부 CT상 간세포암이 발견되어 본원으로 전원되었다. 가족 력상 형이 폐암으로 사망하였고 $30 \mathrm{pack} / \mathrm{year}$ 의 흡연력이 있 었으며 문진소견에서 경미한 복부 불편감이 있었다. 이학적 검사에서 공막의 황달 소견은 없었으며 복부는 편평하고 부 드러웠다. 복부에 압통과 반발통은 없었고 간이나 비장은 명확히 촉지되지는 않았다. 내원 당시 시행한 일반혈액검사 상 백혈구 9,200/ $\mu \mathrm{L}$, 혈색소 $15.6 \mathrm{~g} / \mathrm{dL}$, 혈소판 $1,730,000 / \mu \mathrm{L}$ 이었다. 일반화학검사상 total protein $8.1 \mathrm{~g} / \mathrm{dL}$, albumin $4.6 \mathrm{~g} / \mathrm{dL}$, AST/ALT 46/32 IU/L, total bilirubin $1.5 \mathrm{mg} / \mathrm{dL}$, alkaline phosphatase $137 \mathrm{IU} / \mathrm{L}$, gamma-GT $115 \mathrm{IU} / \mathrm{L}$ 였다. 혈액응고검사상 $\mathrm{PT} 86 \%$ 였으며 종양표지자검사상 AFP 2,220 ng/mL, PIVKA $176 \mathrm{mAU} / \mathrm{mL}$ 였고 바이러스간염표지자 검사상 $\mathrm{HBsAg}(+)$, HBeAg(-), anti-HBe (+), HBV DNA <20 IU, anti-HCV (-)였다.

\section{2. 영상 및 병리 소견}

복부 전산화단층촬영에서 간좌엽을 거의 대체하고 있는 $15 \times 8 \mathrm{~cm}$ 크기의 경계가 불분명한 팽창결절형의 종괴가 관찰 되었고 좌측 문맥 전체와 우측 주문맥에까지 광범위한 혈전 을 동반하고 있었다. 이들 종괴 및 혈전 모두 동맥기에 조영 증강 및 문맥기에 조기배출을 보였고(Fig. 1A, 1B) diffusion restriction을 동반하고 있어(Fig. $2 \mathrm{~A}$ ) 간세포암의 주문맥혈전 증에 합당한 소견을 보였다. 양전자방출단층촬영에서는 종 괴 및 혈전 모두에서 섭취 증가가 관찰되었다(Fig. $3 \mathrm{~A}, 3 \mathrm{~B}$ ).
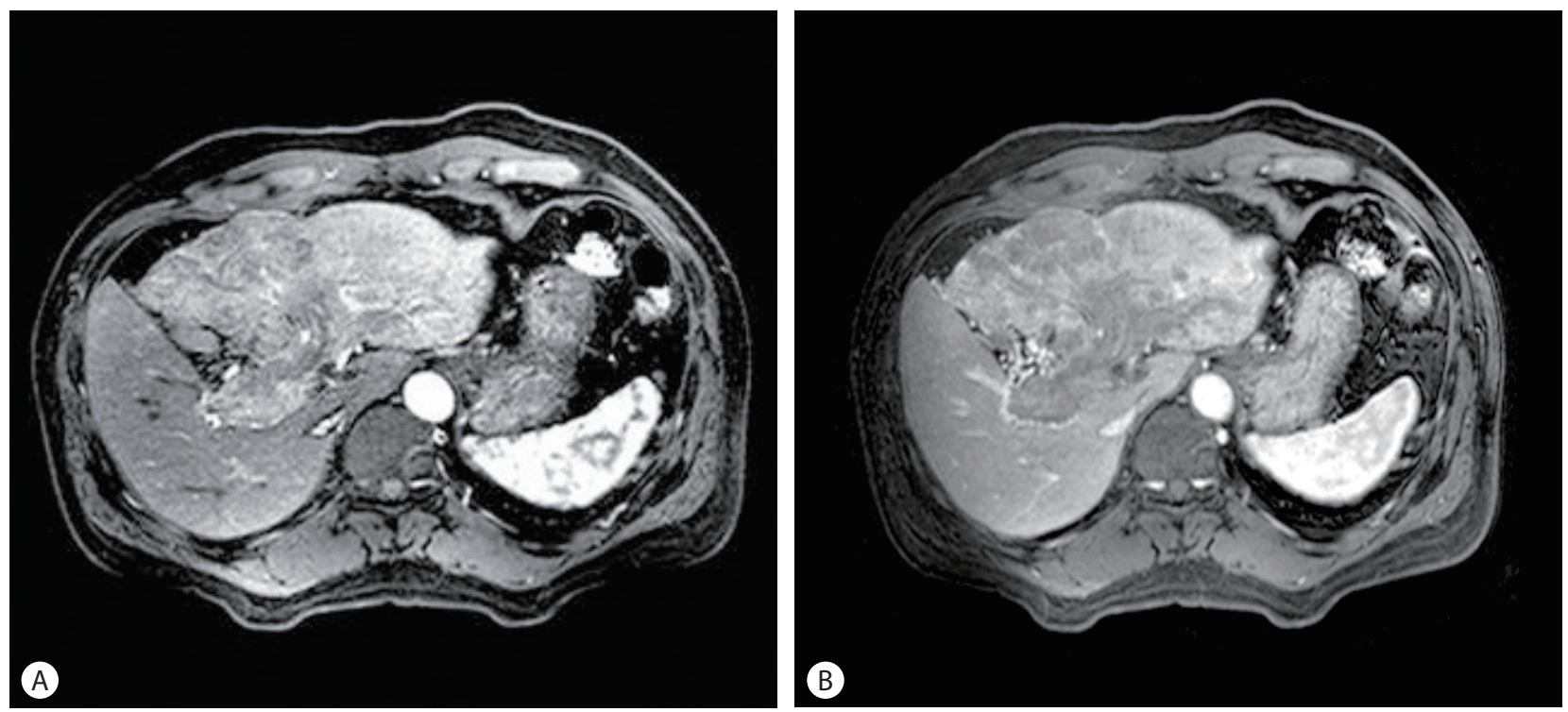

Figure 1. Liver MRI during arterial (A) and portal (B) phase. A $15 \mathrm{~cm}$ sized hepatic mass with early wash-out of contrast were noted in the left lobe. 

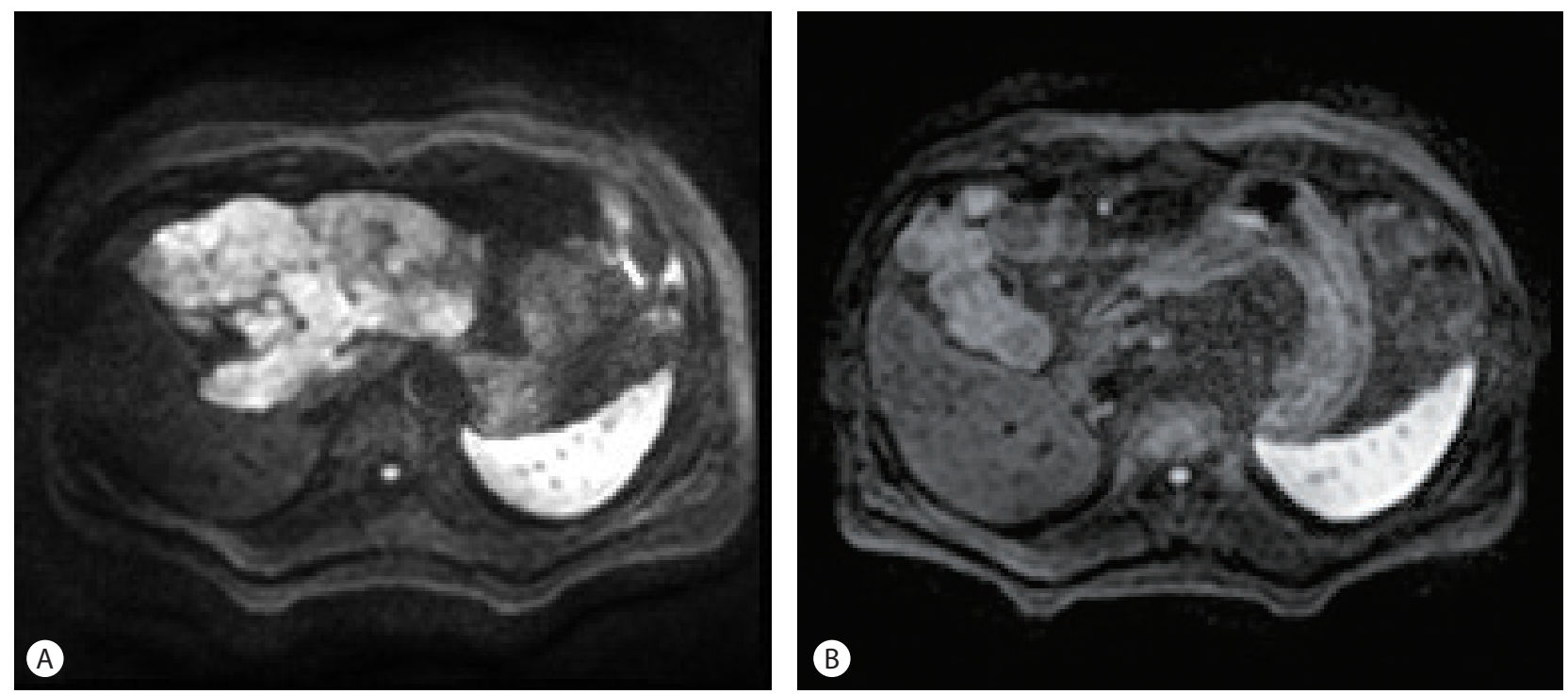

Figure 2. Liver MRI with T2 diffusion weighted images. (A) Initial finding. Huge mass with diffusion restriction were noted. (B) Final finding. Nearly shrunken mass without diffusion restriction were noted.

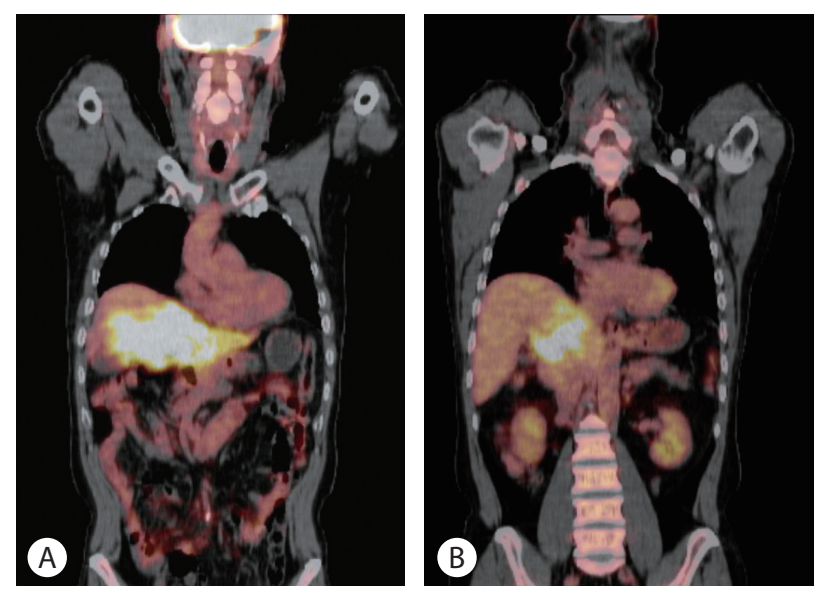

Figure 3. PET-CT scan (Initial finding). Several abnormal uptakes of fludeoxyglucose (FDG) were noted in left hepatic lobe (A) and both portal vein (B).

\section{3. 진단 및 치료 경과}

상승된 종양 표지자와 영상소견에 의해 Child-Pugh A 등 급, 주문맥혈전증을 동반한 간세포암(modified UICC stage IVa)으로 진단하였다. Sorafenib이 표준치료임과 경동맥화 학색전술, 방사선 치료 등을 시도해 볼 수 있음에 대해 설명 후 환자분이 방사선 치료를 시행하기를 원하여 2011년 10월 24 일부터 $36 \mathrm{~Gy}$ 에 3 회로 분할하여 정위 체부 방사선 치료를 계획하였으나(Fig. 4) 2회의 방사선 치료 후 dark urine이 발 생하여 2회, 총 조사선량 $24 \mathrm{~Gy}$ 로 치료를 종료하였다. 방사

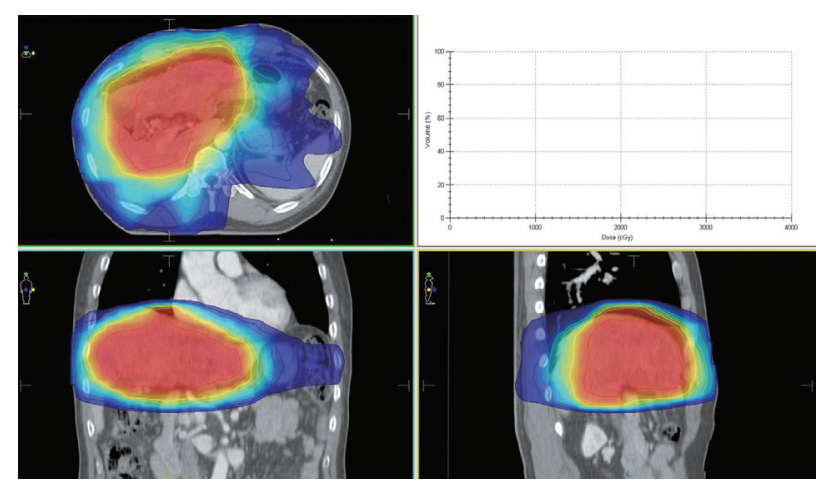

Figure 4. Simulation and planning image of stereotactic body radiation therapy.

선치료 2개월 후 시행한 복부 CT상 좌엽의 종괴는 크기가 확연히 감소하였고 문맥의 종양의 조영증강도 없어졌으나 단순 혈전이 jejuna branch까지 들어차 있는 양상이어서 2011-12-21부터 2012-01-09까지 입원하여 sorafenib $400 \mathrm{mg} /$ day을 복용하면서 와파린을 이용해 항응고치료를 하여 INR 3.0 으로 유지하여 퇴원하였다. 하지만 퇴원 당일 흑색변을 주소로 내원하여 시행한 위내시경상 위전정부에 활성의 궤 양 및 출혈이 관찰되어 sorafenib 중단하고 궤양치료 후 호 전되었고 다시 2012-01-20부터 2012-02-15까지 sorafenib $400 \mathrm{mg} / \mathrm{day}$ 를 다시 유지하며 시행한 복부 CT (방사선치료 3 개월째)상 간좌엽 자체가 거의 위축되어 더 이상의 viable portion이 관찰되지 않았고 문맥혈전 또한 모두 조영증강이 되지 않았으며 같은 시기에 시행한 MRI (Fig. 2B), PET-CT 
(Fig. 5A, 5B)상 유의한 종양 및 문맥혈전에 이전에 관찰되던 diffusion restriction or FDG uptake는 더 이상 관찰되지 않아 mRECIST criteria상 CR로 판단하였다. 이후 2012-02-16부 터 2012년 02-28까지 sorafenib $800 \mathrm{mg} / \mathrm{day}$ 로 증량 후 퇴원 하였으나 그로부터 15일 후에 refractory hiccup과 역류증상 을 주소로 다시 내원하여 시행한 위내시경상 이전에 관찰되 던 전정부 궤양의 범위와 깊이가 증가하면서 일부 omentum으로 생각되는 yellowish fat이 관찰되었고(Fig. 6A), 같 은 시기에 시행한 복부 $\mathrm{CT}$ 상 위궤양 천공이 관찰되었다 (Fig. 6B). PCD를 시행했으나 궤양 천공의 부위가 넓어 2012-03-28 distal gastrectomy를 시행하였으나 수술 2일째에 JP tube로 bile color fluid가 drainage되어 duodenal stump

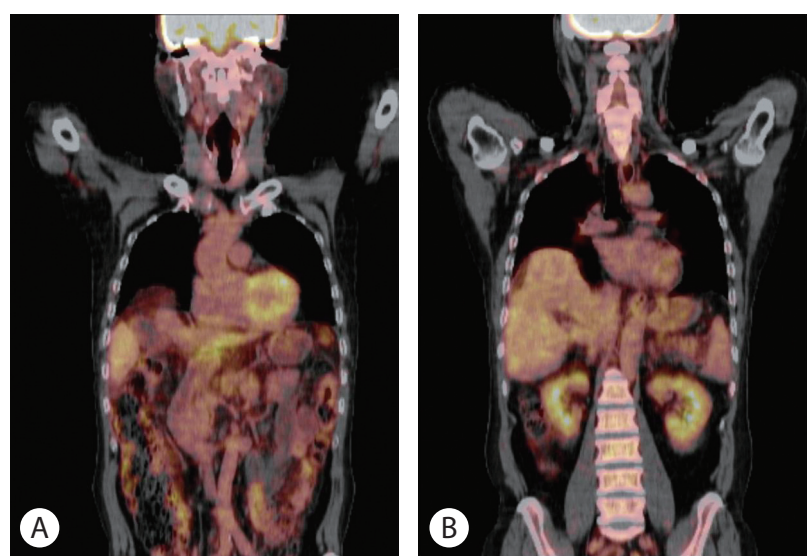

Figure 5. PET-CT scan finding (3 months after SBRT). Previous abnormal uptakes of FDG were disappeared in left hepatic lobe $(A)$ and both portal vein (B).

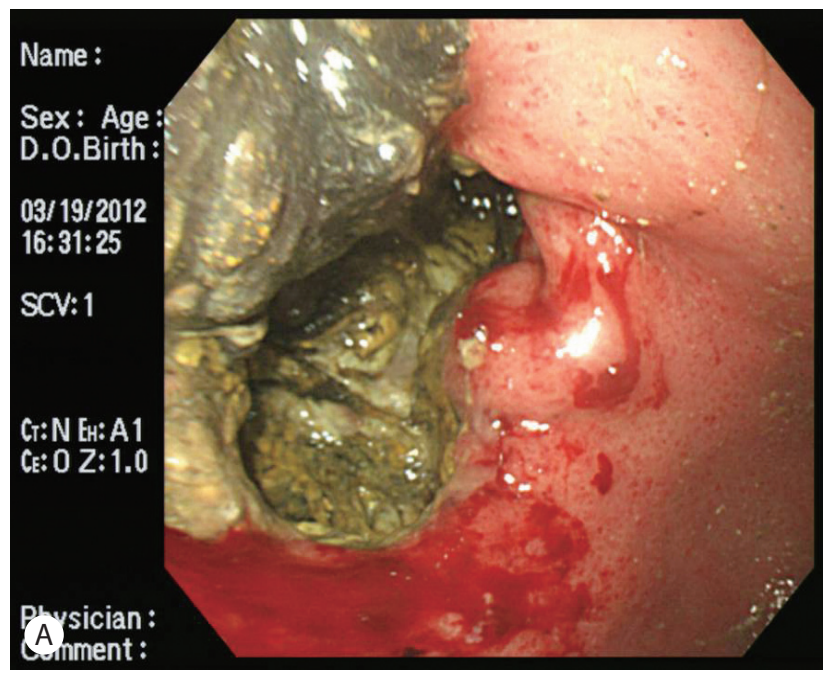

leakage로 생각되었으나 JP drainage가 충분하고 generalized peritonitis의 증상이 없어 경과관찰 중 fever onset하여 이후 $\mathrm{PCD}$ 를 recurrent change \& insertion 시행하였고 leakage site 주위로 controlled fistula를 형성하여 조금씩 retraction하면 서 2014-05-16 JP를 완전히 제거하였고 시행한 UGI series에 leakage 없이 gastrograffin이 passage되는 것을 확인하였다. 향후 치료 위해 2012-05-29 (방사선 치료 7개월째)에 시행한 liver MRI상 S7에 $2.5 \mathrm{~cm}$ 크기의 $\mathrm{HCC}$ 관찰되었고(Fig. 7), 경 동맥화학색전술 계획 중 2012-05-31부터 entecavir $0.5 \mathrm{mg}$ 을 다시 시작했으나 2012-06-04 (entecavir 복용 5일째) total

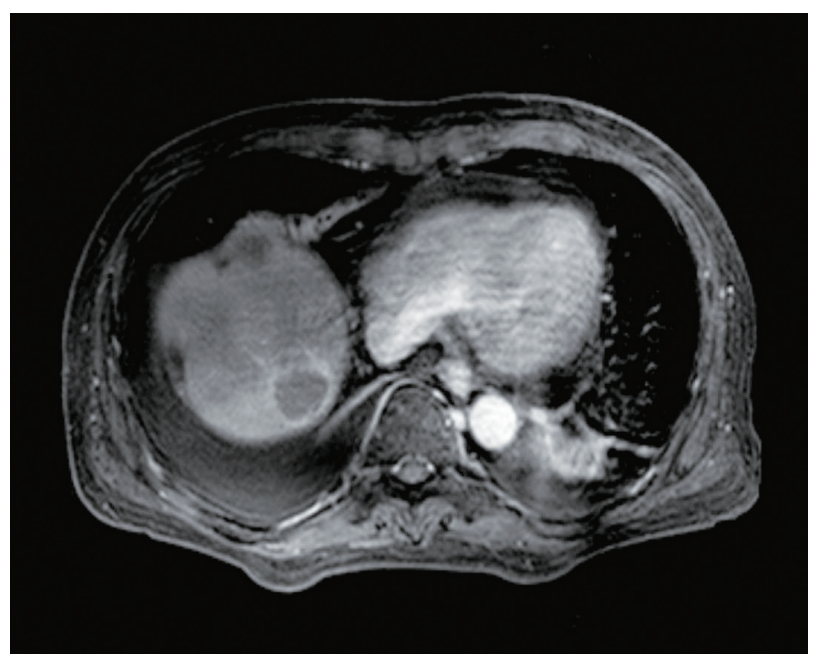

Figure 7. Liver MRI finding after completion of treatment for perforation of ulcer. $2.5 \mathrm{~cm}$ sized hyposingal mass was noted on $\mathrm{S7}$ in hepatobiliary phase.

Figure 6. (A) Esophagogastroduodenoscopy finding. Deep excavating ulcer with suspicious exposed omentum was noted on antrum. (B) Abdominal CT finding. Perforated opening was noted on antrum. 
bilirubin $5.8 \mathrm{mg} / \mathrm{dL}$ (2012-05-31에 $1.3 \mathrm{mg} / \mathrm{dL})$ 으로 증가하였 고 2012-06-06 (entecavir 복용 7일째) $10.1 \mathrm{mg} / \mathrm{dL}$ 으로 증가 하였다. 빌리루빈의 상승을 동반한 의미 있는 간기능의 급 성 악화의 원인 감별을 위해 시행한 lab상 $\mathrm{HBeAg} / \mathrm{Ab}(-/+)$, HBV DNA 29 IU, IgM HBc Ab (-), HCV Ab (-), FANA (-), Anti-smooth muscle $\mathrm{Ab}(-)$, Anti-mitochondrial Ab (-), Anti$\mathrm{LKM} \mathrm{Ab} \mathrm{(-)} \mathrm{check되었다.} \mathrm{Imaging상} \mathrm{S7의} \mathrm{single} \mathrm{HCC이외}$ 에는 다른 병변이 없었고 다른 급성 간염의 원인이 관찰되 지 않으며 간기능 악화를 보인 시점이 entecavir 재투여 5일 째임을 감안하여 2012-06-07 (entecavir 복용 8일째)부터 lamivudine으로 change하여 투여하였으나 빌리루빈 지속적 상승추세 보이며 간부전 진행하였다(Fig. 8).

방사선 치료 10 개월째(빌리루빈 상승 3 개월째) 시행한 PET-CT상 이전에 관찰되던 S7 HCC는 확연히 크기가 증가 하였고 복막전이 등이 발견되었으나 이전에 완전관해를 보 였던 간좌엽의 종괴와 문맥의 종양혈전에는 FDG uptake는 여전히 관찰되지 않고 있었다(Fig 9A, 9B). 이후 간부전이

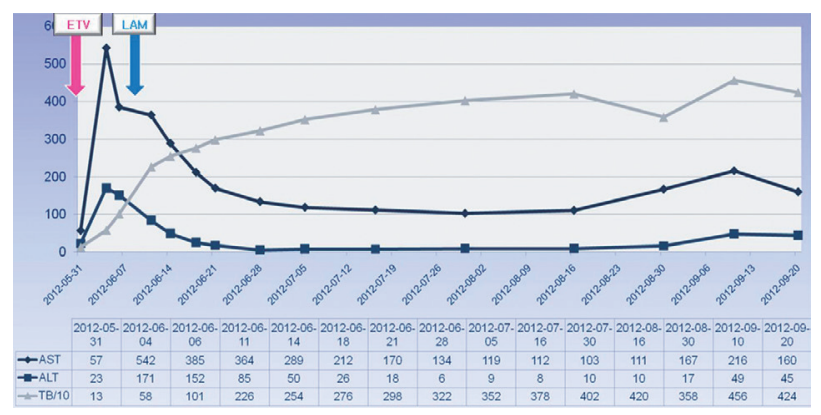

Figure 8. Serial laboratory finding after retreatment of entecavir.
계속 진행하여 2012-09-20 (방사선 치료 11개월째) 사망하 였고 당시 total bilirubin $42.4 \mathrm{mg} / \mathrm{dL}$ 으로 check 되었다.

\section{고 찰}

문맥 침범을 동반한 간세포암에 대해 일본 간학회에서는 sorafenib 외에 경동맥 화학색전술 혹은 외과적 간절제술을 해 볼 수 있다고 제시하고는 있으나 Vp1-2 (둘째 분지)일 때 로 국한하고 있고 ${ }^{1}$ 다른 모든 가이드라인에서는 sorafenib만 을 권고하고 있다..$^{810}$ 하지만 SHARP trial의 subgroup analysis에서 대혈관 침범을 동반한 간세포암의 경우 sorafenib과 placebo 투약에 의한 overall survival은 8.1개월 vs 4.9 개월이 었고 AP trial에서는 5.6개월 vs 4.1 개월로 보고하여 대혈관 침범이 없는 경우에 비해 sorafenib의 효과가 떨어짐을 알 수 있다. 또한 주문맥 침범을 동반한 간세포암의 평균 생존 이 2.7 개월인데 반해 각 trial의 placebo 군에서 4-5개월 정도 의 좋은 평균 생존을 보였다는 것과 각 연구에서 대혈관 침 범의 분류를 정확히 언급하고 있지 않다는 사실을 감안할 때, 소위 'macrovascular invasion group'에 문맥분지혈관( $\mathrm{Vp}$ 1-3) 혹은 간정맥, 대정맥 침범 등의 상대적으로 예후가 좋 을 수 있는 경우가 상당수 포함되었을 가능성이 있다. ${ }^{6.7}$ 따 라서 주문맥 침범을 동반한 간세포암만을 모은 군에서 sorafenib의 효과가 어떠할지에 대해서는 여전히 논란이 있 을 수 있으며 이런 배경에서 경동맥 화학색전술, 방사선치 료, 심지어 간절제술 등의 국소 치료의 단독 혹은 병합에 의 해 좋은 생존율을 보였다는 여러 연구가 있고 임상에서도
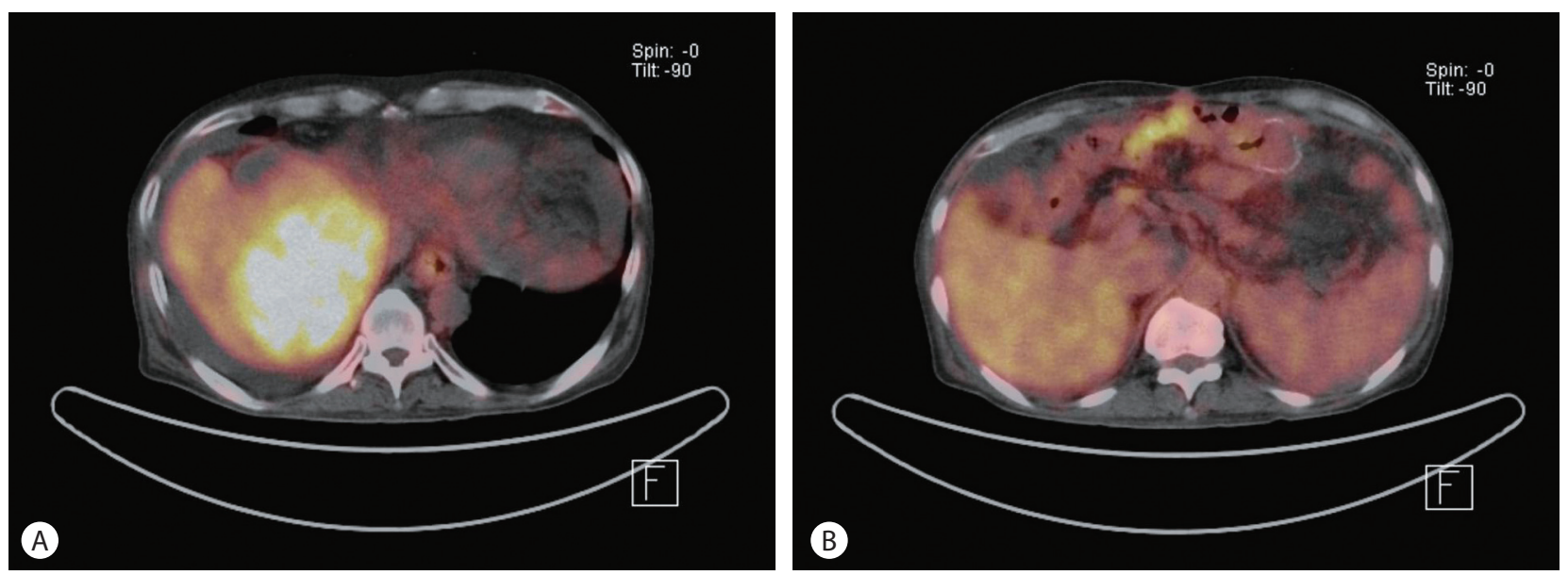

Figure 9. PET-CT scan finding (10 months after SBRT). Abnormal uptakes of FDG that was suggested to growing of previous recurred lesion in Figure 7 was noted (A). Complete disappearance of FDG in left hepatic lobe and both portal vein were still noted (B). 
국소 치료와 전신치료의 병합 등을 시행하고 있기도 하다. 실제 최근의 국내 후향 연구에서 주문맥침범을 동반한 간세 포암 환자 125 명에서 경동맥색전술 단독 치료 시행군과 지 지적 치료 시행군과 비교했을 때 child 등급 $\mathrm{A}$ 환자에서 평균 생존율이 7.4개월 vs 2.6 개월로 좋은 성적을 보고하였다. ${ }^{11}$ 또한 한 연구에서 152 명의 주문맥 침범을 보인 환자를 대상 으로 간절제술을 시행했을 때 평균 생존 10.1 개월의 좋은 성 적을 보고하였다. ${ }^{12}$ 또한 국내의 한 연구에서는 주문맥 침범 을 동반한 127 명의 환자에서 방사선 치료를 시행했을 때 7.7 개월의 평균성적을 보고하기도 하였고 ${ }^{13}$ 비록 $\mathrm{Vp} 3-4$ 가 혼재 한 군이긴 했으나 136-326명의 환자군에서 9-13개월의 평균 생존율을 보고하기도 하였다. ${ }^{14}$

최근 방사선 의학의 발전으로 주위 장기 손상을 최소화하 면서 고용량의 방사선을 3 회 내외의 짧은 횟수로 조사하는 정위 체부 방사선 치료(Stereotactic Body Radiation Therapy, $\mathrm{SBRT}$ )란 개념이 생기면서, 기존에 저용량의 방사선으로 6 주 정도로 치료하는 것에 비해 방사선생물학적으로 더 좋은 종양효과를 보일 수 있을 것으로 기대하고 있다. 주문맥 침 범만을 대상으로 한 연구는 없지만, 국내 소규모 연구에서 9 명의 문맥침범 환자에서 SBRT 시행 결과, 8 개월의 평균 생 존을 보였고 ${ }^{15}$ 해외의 1,2 상 연구에서 문맥침범환자가 $50 \%$ 이상 포함된 군을 대상으로 SBRT 시행 결과, 17 개월의 평균 생존(10.4-21.3개월)이라는 결과를 보여주기도 하였다. ${ }^{16}$

SBRT에 의한 grade 4 의 위장관 독성(궤양의 출혈 혹은 천 공) 발생률은 $4 \%$ 정도로 보고하고 있는데 ${ }^{16,17}$ 이 증례의 경 우 위장에 피폭량이 그리 많지 않아 방사선 치료에 의한 천 공이라기 보다는 이후에 투여한 sorafenib이 추가적인 역할 을 했을 가능성이 있을 수 있다. 실제 한 연구에서 SBRT 후 VEGF inhibitor를 투여받은 76명의 환자를 대상으로 조사했 을 때 SBRT 시행 3개월 이내에 VEGF inhibitor를 투여한 환 자군에서 serious bowel injury가 발생할 확률이 hazard ratio 19.1로 가장 높았고 위장에 피폭된 방사선량과는 연관성이 없는 것으로 보고하였다. ${ }^{18}$

이 증례에서 가장 의문이 남는 부분은 위천공을 치료한 후 entecavir 투여 5일째부터 발생한 빌리루빈 상승을 동반 한 급성 간부전의 원인이 무엇인가 하는 것이다. 간부전 악 화시점에 시행한 영상의학적 검사상 $2.7 \mathrm{~cm}$ 정도의 single $\mathrm{HCC}$ 만 있어 간세포암의 진행에 의한 간부전으로 보기는 힘들것이다. 일단 방사선 유발 간질환(Radiation Induced Liver Disease, RILD)에 의한 간부전일 가능성이 있겠는데, 실제 한 연구에서 간문맥 침범이 광범위하고 간섬유화가 진
행될수록 RILD 위험이 증가함을 보고하기도 하였다. ${ }^{19}$ 하지 만 대부분의 RILD가 방사선치료 4-8주에 시작되어 3-5개월 안에 호전되며 이 증례의 경우 SBRT 7개월째에 갑자기 발 생한 것을 감안할 때 전형적인 RILD의 경과와는 맞지 않는 면이 있다. 간부전 발생의 시점만을 본다면 entecavir의 투여 가 원인으로 가능할 수 있겠는데, 한 연구에서 만성 B형 간 염의 심한 급성 악화 시 entecavir의 투여가 lamivudine 투여 에 비해 장기적인 바이러스 반응을 더 좋게하지만 황달, 복 수, 간성 혼수 등의 간부전은 오히려 증가되어 단기 사망률 은 늘인다고 보고하였다. ${ }^{20}$ 하지만 이후의 연구들 ${ }^{21,22}$ 에서 entecavir가 lamivudine에 비해 단기 사망률을 증가시키지 않는다고 보고하고 있어 이 증례에서 entecavir의 투여를 간 부전의 원인으로 단정짓기에는 힘든 면이 있다. 다만 추적 영상의학적 검사에서 간우엽의 위축이 지속되는 것을 감안 할 때 fibrosis의 진행을 동반한 RILD가 어느 정도 있어 간기 능이 vulnerable한 상태에서 entecavir의 재투여로 인해 촉발 된 간부전이었을 가능성도 생각해 볼 수 있겠다.

요컨대 이 증례는 주문맥 침범을 동반한 거대 간세포암에 서 정위 체부 방사선 치료와 sorafenib의 투여를 통해 종양 및 주문맥 혈전증의 완전 관해를 이루었으나 치료 부작용으 로 위궤양이 천공이 발생하였고 이후 수술과 중재적 시술을 통해 위궤양 천공 완치 후에 항바이러스 제재의 재투여 후 간부전이 발생하여 방사선 치료 11 개월 만에 사망한 증례이 다. 주문맥 침범을 동반한 간세포암에서 방사선 치료를 포 함한 국소 치료 및 전신 치료의 병합을 통한 다학제적 접근 이 기존의 불량한 치료 성적을 개선시킬 수 있을 것으로 기 대되지만 여러 치료의 개입으로 인한 부작용의 증가, 특히 방사선 치료와 sorafenib의 병용 시 발생할 수 있는 위장관 독성 등에 대해 고려할 필요가 있으며 이에 대한 추가 연구 가 필요하다고 하겠다.

중심 단어: 간세포암; 문맥침범; 정위체부방사선치료; 소라 페닙; 위궤양 천공

\section{Conflicts of Interest}

The authors have no conflicts to disclose.

\section{REFERENCES}

1. Ikai I, Arii S, Okazaki M, Okita K, et al. Report of the 17th nationwide follow-up survey of primary liver cancer in Japan. Hepatol Res 


\section{7;37:676-691.}

2. Pirisi M, Avellini C, Fabris C, et al. Portal vein thrombosis in hepatocellular carcinoma: age and sex distribution in an autopsy study. J Cancer Res Clin Oncol 1998;124:397-400.

3. Stuart KE, Anand AJ, Jenkins RL, et al. Hepatocellular carcinoma in the United States. Prognostic features, treatment outcome, and survival. Cancer 1996;77:2217-2222.

4. Park KW, Park J, Choi Jl, et al. Survival analysis of 904 patients with hepatocellular carcinoma in a hepatitis B virus-endemic area. J Gastroenterol Hepatol 2008, 23:467-473.

5. Llovet JM, Bustamante J, Castells A, et al. Natural history of untreated nonsurgical hepatocellular carcinoma: rationale for the design and evaluation of therapeutic trials. Hepatology. 1999;29:6267.

6. Cheng AL, Guan Z, Chen Z, et al. Efficacy and safety of sorafenib in patients with advanced hepatocellular carcinoma according to baseline status: subset analyses of the phase III Sorafenib AsiaPacific trial. Eur J Cancer 2012;48:1452-1465.

7. Bruix J, Raoul JL, Sherman M, et al. Efficacy and safety of sorafenib in patients with advanced hepatocellular carcinoma: subanalyses of a phase III trial. J Hepatol 2012;57:821-829.

8. Bruix J, Sherman M. Management of hepatocellular carcinoma: An update. Hepatology 2011;53:1020-1022.

9. Omata $M$, Lesmana LA, Tateishi $R$, et al. Asian Pacific Association for the Study of the Liver consensus recommendations on hepatocellular carcinoma. Hepato Int 2010;4:439-474.

10. de Lope CR, Tremonsini S, Forner A, et al. Management of HCC. J Hepatol 2012;56 Suppl 1:S75-87.

11. Chung GE, Lee JH, Kim HY, et al. Transarterial chemoembolization can be safely performed in patients with hepatocellular carcinoma invading the main portal vein and may improve the overall survival. Radiology 2011;258:627-634.

12. Chen $X P, Q i u ~ F Z, W u Z D$, et al. Effects of location end extension of portal vein tumor thrombus on long-term outcomes of surgery treatment for hepatocellular carcinoma. Ann Surg Oncol
2007;13:940-946.

13. Yu Jl, Park HC, Lim DH, et al. Prognostic index for portal vein tumor thrombosis in patients with hepatocellular carcinoma treated with radiation therapy. J Korean Med Sci 2011;26:1014-1022.

14. Kim JY, Chung SM, Choi BO, et al. Hepatocelluar carcinoma with portal vein tumor thrombosis: Improved treatement outcomes with external beam radiation therapy. Hepatology Research 2011;41:813824.

15. Chio BO, Choi IB, Jand HS, et al. Stereotactic body radiation therapy with or without transarterial chemoembolization for patients with primary hepatocellular carcinoma: Preliminary analysis. BMC Cancer 2008;8:351-358.

16. Bujold A, Maasey CA, Kim JJ, et al. Sequential phase I and II trials of stereotactic body radiotherapy for locally advanced hepatocellular carcinoma. J Clin Oncol 2013;31:1631-1639.

17. Kang JK, Kim MS, Chol CK, et al. Stereotactic body radiation therapy for inoperable hepatocellular carcinoma as a local salvage treatment after incomplete transarterial chemoembolization. Cancer 2012;118:5424-5431.

18. Barney BM, Markovic SN, Laack NN, et al. Increased bowel toxicity in patients treated with a vascular endothelial growth factor inhibitor (VEGFI) after stereotactic body radiation therapy (SBRT). Int J Radiat Oncol Biol Phys 2013;87:73-80.

19. Liang $S X$, Zhu XD, Xu ZY, et al. Radiation-induced liver disease in three-dimesional conformal radiation therapy for primary liver carcinoma: the risk factors and hepatic radiation tolerance. Int J Radiat Oncol Biol Phys 2006;65:426-434.

20. Wong VW, Wong GL, Yiu KK, et al. Entecavir treatment in patients with severe acute exacerbation of chronic hepatitis B. J Hepatol 2011;54:236-242.

21. Liu C, Ye J, Jia H, et al. Entecavir and lamivudine therapy for severe acute chronic hepatitis B. Exp Ther Med 2013;5:545-548.

22. Chen $\mathrm{CH}$, $\mathrm{Lin} \mathrm{CL}, \mathrm{Hu} \mathrm{TH}$, et al. Entecavir versus lamivudine in chronic hepatitis $B$ patients with severe acute exacerbation and hepatic decompensation. J Hepatol 2014 Feb 25 [Epub]. 